\title{
The Garden and the Market: Human-Environment Relations and Collective Imaginary in Afro-Brazilian Candomblé between Italy and Brazil
}

\author{
Giovanna Capponi iD http://orcid.org/0000-0002-7196-3627 \\ Department of Life Sciences \\ University of Roehampton \\ giovanna.capponi@gmail.com
}

\begin{abstract}
This paper explores Candomblé rituals from the perspective of human-environment relations, taking into account not only human followers, but also animals, plants and artefacts that are necessary for the making of Candomble terreiros. While this process of interaction between different realms is codified by strict rules and prescriptions, it also adapts according to the environment where the Candomblé community is located. Drawing from fieldwork data collected in a Candomblé terreiro that has been active in Italy for almost two decades, this paper aims at presenting the challenges and adaptations of the religious practice in different natural landscapes. By taking into account the spatial composition and the material culture involved in the Italian terreiro and its references in Brazil, this work re-thinks how Candomblé practitioners relate to the cultural and ecological environments.
\end{abstract}

Keywords: Candomblé, transnationalization, Afro-Brazilian religions, anthropology of ritual, human-environment studies, multispecies ethnography

Słowa kluczowe: Candomblé, transnacjonalizacja, religie afro-brazylijskie, antropologia rytuału, studia nad środowiskiem ludzkim, etnografia wielogatunkowa

Candomblé Ketu is a religious system that originated in Brazil, but it took its cue from the West African cult of the orixás (in the Portuguese spelling), deities who were worshipped in the Yoruba kingdoms. Offerings, sacrifices and chanting were performed as part of a wider way of being-in-the-world, and "religious" practices were embedded in social relations, kinships and hierarchies within the city-state. ${ }^{1}$

${ }^{1}$ K. Barber, How Man Makes God in West Africa: Yoruba Attitudes towards the 'Orisa', "Africa: Journal of the International African Institute" 1981, no. 51(3), pp. 734-745. 
As Candomblé is often described as a "religion of nature," I have been interested in exploring how a particular idea of "nature" is constructed in different environmental settings. In order to do this, I took into consideration the ecological and social adaptations of a Candomblé house (also known as terreiro) founded in Arborio, in the Piedmont region of Northern Italy. Only part of my fieldwork has been carried out in Brazil (particularly in the area of São Paulo), where I spent a total of six months of research, while I consider the Italian Candomblé house to be my main research site. The terreiro of Arborio, called Ilê Axé Alaketu Aira, was founded at the end of the 1990s by an Italian pai de santo (Candomblé priest) who, after his initiation into Candomblé in São Paulo, Brazil, decided to open a new temple in Italy. The worship house is attended by both Brazilian immigrants and Italian converts who identify with the religious system. This community regards Brazilian houses (at least those in the same "lineage," in which the Italian pai de santo was initiated) as its role model. At the same time, this diasporic process requires a creative adaptation to a different social and ecological environment.

I started my fieldwork with the intention of following the network of my first interlocutors, the members of the Candomblé house of Arborio, and to trace its history and its ties with various Brazilian Candomblé houses in São Paulo. Once in Brazil, my personal network expanded and allowed me to explore and have contacts with other, unrelated, Candomblé and Umbanda ${ }^{2}$ terreiros in urban and metropolitan areas. Therefore, my fieldwork did not take the form of a proper comparative analysis between two groups; it was rather shaped in terms of a more general enquiry into how different religious communities perceive and relate to the environment through Candomblé ritual practices. However, the Italian case study stands out as an interesting example of how codified cultural practices such as rituals are adapted and re-shaped in different socio-ecological conditions. For these reasons, this research was aimed at contributing not only to the field of human-environment studies but also to the wider literature on the spread of Afro-Brazilian religions outside Brazilian national borders. ${ }^{3}$

\section{From Arborio to Bahia}

I have been conducting research in the Ilê Axé Alaketu Airá since $2008,{ }^{4}$ maintaining regular contacts (and eventually developing ritual ties) with Pai Mauro, the founder

${ }^{2}$ Another Afro-Brazilian religion which incorporates not only the orixás but also entities, spirits and Catholic saints.

${ }^{3}$ For references to Afro-Brazilian religions in other European contexts, see the works of J. Bahia (De Miguel Couto a Berlim: a presença do candomblé brasileiro em terras alemãs, [in:] Migração e globalização: um olhar interdisciplinar, G.M.S. Pereira, J. de Ribimar Sousa Pereira (eds.), Curitiba 2012, pp. 181-212) in Germany; C. Saraiva (Afro-Brazilian religions in Portugal: bruxos, priests and pais de santo, "Etnográfica" 2010, no. 14(2), pp. 265-288) in Portugal; and A. Halloy (Um candomblé na Bélgica. Traços etnográficos de uma tentativa de instalação e suas dificuldades, "Revista de Antropologia - USP" 2004, no. 47(2), pp. 453-493) in Belgium, amongst others. Some pioneer studies in the Italian context were conducted by Faldini in the late 1990s.

${ }^{4}$ I conducted research for my BA dissertation, and I complemented and re-thought those data during my $\mathrm{PhD}$ research in 2014-2017. 
of the terreiro, and his familha de santo (religious family, community)..$^{5}$ The peculiar story of Pai Mauro deserves to be told in more detail. Born in Milan at the end of the 1960s, he is the nephew of a cartomancer who introduced him to the world of fortune-telling early in his life. At the age of 17, Mauro started working together with his aunt, gaining popularity in the same field and acquiring specific skills like card reading, pendulum dowsing and other fortune-telling techniques. ${ }^{6}$ During a trip to Brazil, he started to develop an interest in Afro-Brazilian magico-religious practices. He contacted a pai de santo from the Brazilian city of Recife and decided to find help in setting up a specific space to perform Afro-Brazilian rituals in Milan. By his own admission and up to that point, Mauro's actions were motivated mostly by his professional interests. However, while performing rituals in the new space, an unexpected event began to undermine his utilitarian perspective.

Pai Mauro: But when this person came from Brazil to help a particular, strange energy, which I did not know, which I did not understand, took possession of my body instead. It made me say and do strange things [...] I did not know how to speak Portuguese at the time, but this energy which took possession of my body spoke in Portuguese.

Therefore, Mauro unexpectedly became the protagonist in a case of spirit possession and speaking-in-tongues that brought him to reflect upon his personal and spiritual involvement. Pai Mauro's personal experience fits other authors' analyses in which Brazil is a place of "spiritual magnetism," which attracts westerners who are seeking healing, spirituality and the "transformation of the self."

After a few months, his doubts were cleared by his encounter with another pai de santo from São Paulo, Pai Taunderan, ${ }^{9}$ whom he met in Milan at a Latin-American festival. The Festival Latinoamericando is a themed festival that takes place every summer in Assago (Milan). Besides being a venue for concerts and dance nights, the festival hosts a fair with different stands selling theme-related street food and artisanal objects. In the late 1990s, Pai Taunderan started working at the festival

${ }^{5}$ The people who belong to a religious community would identify as sons and daughters of the Candomblé house they attend (filhos de santo) and the spiritual leader is regarded as a pai or mãe de santo. These terms have been often literally translated as "son/daughter of the saint" and "father of the saint" (cf. C. Saraiva, op. cit., amongst many others). However, I would like to break from this well-established tradition in the anglophone literature and attempt a different translation. In fact, the word santo does not only refer to the orixás but to a whole world of sacred and sanctified artefacts, places and bodies. Therefore, I will use the terms "sacred father," "sacred mother" and "sacred sons/daughters" in order to better render the implications of the initiation process in terms of kinship and "sacredness."

${ }^{6}$ Such practices could be understood as inscribed in a continuum between esoterism and New Age spirituality, as it emerges in other works (see V. Teisenhoffer, Umbanda, New Age et psychothérapie. Aspects de l'implantation de l'umbanda à Paris, "Ateliers du LESC" 2007, no. 31, http://journals.openedition.org/ateliers/872 [access: 08.12.2018]), and in the works of Golfetto and Bahia in Italy and Germany (in this volume), who analyse how Candomblé world views overlap with activities such as reiki and energetic cleanses.

7 J. Preston, Spiritual Magnetism: An Organizing Principle for the Study of Pilgrimage, [in:] Sacred Journeys: The Anthropology of Pilgrimage, A. Morinis (ed.), London 1992, p. 33.

${ }^{8}$ M.A. Vásquéz, C. Rocha, Introduction: Brazil in the New Global Cartography of Religion, [in:] idem, The Diaspora of Brazilian Religions, Leiden 2013, pp. 1-42.

${ }^{9}$ See the article of Golfetto in this volume, who analyses other Candomblé terreiros in Rome and Vigevano. 
running his own stall selling Brazilian artisanal items, but also performing jogo de búzios (cowrie shell divination) for clients and attendees. The jogo de búzios is very common in Brazil in the same way that tarot reading is popular in many European countries. The clients who require these types of services do not necessarily have an interest in the religious background of Candomblé or Umbanda, but they will trust and pay those who can perform the rituals in order to analyse and solve personal problems concerning their love lives, financial situations, and their spiritual and physical wellbeing. For the duration of my fieldwork the Latin-American festival of Assago has been often mentioned as a sort of "place of recruitment" of potential clients, sympathisers and also initiates.

Indeed, Mauro's jogo de búzios revealed that his destiny was to become a Candomblé sacred father, so he decided to follow Pai Taunderan to São Paulo and undergo the initiation rituals. He became dedicated to the orixá Airá (deity of the thunder) and from that moment he embraced the Candomblé religion beyond his professional interests. In Pai Mauro's detailed account, the process of looking for a suitable house for his purpose was full of coincidences, strange circumstances and unforeseen situations which led him to find the farmstead of Arborio where the terreiro is now located, in a flat rural area surrounded by rice paddies, a typical crop of Northern Italy.

After a few years in the mid-2000s, the relationship between Pai Taunderan and Pai Mauro turned sour, and Pai Mauro chose Pai Odé (a Brazilian priest belonging to the same Candomblé family) as his new pai de santo and point of reference. Consequently, Pai Odé became one of the most important contacts for my fieldwork in Brazil. In the attempt to track back his sacred genealogy, I also visited his sacred father, Pai Kabila, and his terreiro in the municipality of Barueri (São Paulo). I also had the opportunity to travel to Salvador, Bahia, and to visit the House of Oxumaré (Casa de Oxumaré, one of the most ancient Candomblé houses of Brazil) now led by Babá Pecé. These visits helped me to better understand the constant processes of adaptation and renegotiation that Candomblecists experience in different settings. Tracing back the network and the sacred family from Arborio to Salvador sheds light on the complex ways in which a ritual can be reshaped from a rural to an urban environment, from the most traditional background of Bahia to the modern metropolis of São Paulo and from the coasts of Brazil to the Italian villages of Piedmont.

\section{The House and the Forest}

As a result of the Trans-Atlantic Slave Trade, the reconfiguration of ritual and social bonds and familiar ties in the diaspora took place in the terreiros, "sacred spaces" that concentrated for the first time the cults of different orixás, which were kept separated in the African architectonical and urban structure. Roger Bastide defines the terreiro as a "little Africa", a place that fulfills the need for a new social and familiar environment. In this context, according to Sodré, ${ }^{10}$ the building of a new spatial

${ }^{10}$ Sodré M., O terreiro e a cidade: a forma social Negro-Brasileira, Rio de Janeiro 2002. 
organisation was a way of escaping the subaltern conditions that the slaves lived under in the colonial society. However, the choice of where to locate Candomblé houses was also guided by the fact that these practices had suffered persecution for decades. The typical location of the terreiros was the roça, indicating a deforested space, but more generally suggesting a house just outside the urban area, in the country or on the periphery. Nowadays, roça is a colloquial term to describe the worship house itself. Santos ${ }^{11}$ finds an exemplar model of the typical terreiro in the famous Asè Òpó Afònjá in Salvador. She divides it into two parts: 1) the urban space, including the salon (barracão) where the public festivals are performed, the rooms or small shacks (igbas, or assantamentos) where the shrines of the orixás are kept, and the kitchen and other facilites; 2) the wild space (mato, "forest"), a garden that includes trees and water springs, but also the plants used in the rituals.

In this microcosmos, the political and ritual elements of the African urbs and the natural elements seem to be part of a process of re-territorialisation of the slaves' society in the new environment. Sodré points out how the division between the "natural" space and the urban space recreates the basic structure of Yoruba royal palaces, called afin. The afin was not only the residence of the obá, the king, but also the location where many temples and shrines of different orixás were kept. Moreover, almost all Yoruba palaces were surrounded by a large portion of forest. The Nigerian historian and geographer G.J. Afolabi $\mathrm{Ojo}^{12}$ gives a detailed account of the structure of the afin, the royal residence of the Yoruba king. The typical features of Yoruba afin include an extensive market-place situated at the entrance of the palace, a huge courtyard where people could gather in assemblies, the building itself, and grounds which often covered large areas of territory. The forest element was sometimes partially cultivated, but in most cases it was kept wild in order to constitute a hunting reserve for the king, or for local doctors to grow medicinal plants in secrecy. ${ }^{13}$ Certainly the dense African forest cannot be reproduced quantitatively in the back garden of a terreiro, but it is common for Candomble priests to cultivate in these gardens - or reterritorialised forests - the plants they need for some rituals to be performed.

It is important to note that the absence of intense farming is often replaced by different sorts of horticultural practices. These are subtle ways of creating the conditions for the forest to grow and to provide certain fruits instead of others. As shown by many researchers in ethnobotany, indigenous peoples who sustain themselves through hunting and gathering alter their environment and make it possible for their favourite plant species to flourish and become prevalent in the specific area they inhabit. ${ }^{14}$ These small-scale practices of forest manipulation shed a different light on what is to be considered a domestic or a wild environment and the ways humans perceive their presence in the world. This same concept has been explored by Balée

${ }^{11}$ J.E. dos Santos, Os Nagô e a morte: pàde, àsèsè e o culto égun na Bahia, Petrópolis 2002, pp. $33-34$.

${ }^{12}$ G.J. Afolabi Ojo, Yoruba Palaces: A Study of Afins of Yorubaland, London 1966.

${ }^{13}$ Ibidem, p. 36.

${ }_{14}$ R.A. Voeks, Sacred Leaves of Candomblé: African Magic, Medicine and Religion in Brazil, Austin 1997, p. 19. 
in his definition of "historical ecology" as a discipline that "focuses on the interpenetration of culture and the environment, rather than on the adaptations of humans to the environment." 15 In this way the author highlights the fact that the relationship between nature and culture is dialogical rather than dichotomical, and that the ecological landscape is the result of human activity rather than a determinant factor for the development of human cultural practices. As argued by Descola in his account on the Achuar of upper Amazon, it is not the garden that replicates the qualities of a forest, but the forest which should be considered a huge garden in the first place. Somehow, the espaço mato (wilderness) of Candomble terreiros (and of the Yoruba afins) could be described along the lines of what Descola calls the "homely wilderness": ${ }^{16}$ a continuum in the presence-absence of humans within the environment.

Most Candomblé houses that I visited during my fieldwork somehow followed this same spatial structure to various degrees. In Brazil, Pai Odé runs two Candomblé houses: one set in the urban area of São Paulo, in the neighbourhood of Ipiranga, the other in a forested area not far from Juquitiba, situated approximately $75 \mathrm{~km}$ from São Paulo.

Pai Odé [talking about the Candomblé house in Ipiranga]: We used to have a lot of forested and green spaces, rivers, land, water around here. [...] When we had to perform an obrigação [Candomblé rite of passage], we used to walk over there, we used to cross the high road and here we used to find leaves, trees, water, land. [...] But then the progress came, isn't it true? It came and took control, the concrete jungle dominated [...]. I had to come up with an alternative solution, I had to find a space which could serve the cult of the orixás in the best and most appropriate way. There are many different things nowadays, we already said that we have to adapt, if I had to do a bori (ritual of preparation) for you here today, it would be very different from the one I would do there. Not because of the basis, the ritual, but because of the material I would use... because there [in the rural terreiro] I get water from the spring, here [in the urban terreiro] I get water from the tap, here it is a processed water, while over there it is pure. Here I take a leaf from a potted plant, while there I will take directly from the forest [...]. See how the ritual process becomes different.

As explained in his own words, there is a practical reason for the sacred father to run two Candomblé houses. In fact, as the Ipiranga neighbourhood underwent urban development and the landscape changed, Pai Odé decided to find another place closer to the natural elements. However, Pai Odé's urban sacred space remains a convenient place to receive his clients, who can now have the shells read and other rituals performed for them without having to leave the city.

Indeed many terreiros now situated in urban environments were initially founded in forested and unoccupied peripheries. The need for a more rural and forested ritual space seems to be based on the assumption that Candomble rituals can be performed more easily in such environments. This is not only because rituals would be performed closer to the natural elements of the orixás, but also because the effects of the rituals are considered to be "purer," stronger and more immediate according to the

${ }_{15}$ W. Balée, Historical Ecologies: Premises and Postulates, [in:] Advances in Historical Ecology, W. Balée (ed.), New York 1998, p. 14.

${ }^{16}$ P. Descola In the Society of Nature: A Native Ecology of Amazonia, Cambridge 1994, p. 220. 
quality of the ingredients that are used. It is commonly held that a higher concentration of axé (sacred energy) can be obtained by using elements that are as close as possible to a particular idea of nature. Indeed, the original African land that populates the rhetoric and discourses of Candomble practitioners ${ }^{17}$ and its untouched forests represent that ideal type of nature where energies are considered to be in their purest and most authentic state. However, in the diaspora these spaces and these ideal environments are constantly being re-adapted and re-territorialized.

For example, Pai Kabila's terreiro in Barueri has small plots that can be used to grow plants and place entities, and some assentamentos are situated under trees across the road. This is a very common solution for terreiros whose area has undergone rapid urban development, shrinking the amount of available green areas to small patches in the courtyard or even replaced by potted plants.

Despite being located in an area of Salvador that is now very urbanized, the House of Oxumaré has a much bigger plot of land, where animals are kept and trees and plants are grown for ritual purposes, although the house still relies on specialised markets for some ritual ingredients or for live animals. Be it for the provisioning of animals, specific herbs or food items, Candomblé houses are rarely completely self-sufficient, and they constitute the backbone of a specialized market of ritual and non-ritual elements, ingredients, and artefacts.

\section{Imaginary and global universes of consumption}

Candomblé temples not only condense and integrate the mythical cosmology and the geographical universe of the Yoruba social structure, but they are also an extraordinary repository of what I will call "biodiversity." By biodiversity I am not simply referring to a physical bio-ecological environment, but to something much wider: the result of the interactions among different natural and supernatural species, energies, ingredients, materials and artefacts that are needed in order to perform the rituals correctly. As a sacred mother told me in the Italian terreiro, "a Candomblé house must contain all types of energies."

Vogel, Mello and Barros ${ }^{18}$ mention this kind of diversity not within the borders of the sacred space, but in the place where these items are acquired: the marketplace. In fact, as is often the case in Salvador, a novice who is preparing for his/her initiation has to go to the market together with an elder, to learn how to distinguish suitable from unsuitable ingredients.

All the items that can be found in the market are necessary for the rituals, and large quantities of these ingredients can be found in Candomblé terreiros. However, while the market can be seen as a chaotic and baroque mixture of different objects, plants, and animals, in the Candomblé house these items are re-culturalized into a new meaningful order.

${ }^{17}$ S. Capone Searching for Africa in Brazil. Power and Tradition in Candomblé, London 2010.

${ }_{18}$ A. Vogel, M.A.S. Mello, J.F.P. Barros, A galinha-d'angola: iniciação e identidade na cultura afro-brasileira, Rio de Janeiro 1993. 
The classic accounts of the Afro-Brazilian market described by Vogel, Mello, and Barros ${ }^{19}$ represent an imagined and "traditional" situation in which ritual commodities can be found in a chaotic and baroque setting. This modality of an imagined and typical marketplace is represented by the Feira de São Joaquim in Salvador, Bahia: a dark and intricate labyrinth of alleys where vendors sell all sorts of fruit, grains, baskets, and pots, but also ritual images, leaves and special ingredients, and where large numbers of items are displayed on the stalls, hanging from the roof, or piled on tables and shelves. At the entrance to the covered market, a large statue of the orixá Exú (protector of money, transactions and communication) welcomes the customers, who normally throw a couple of coins at his feet as an extemporary offering as they walk in. The presence of this image is further proof of the ties that intertwine between this particular modality of the marketplace and the Candomblé imaginary.

However, this evocative version of the Afro-Brazilian market dissolves and becomes fragmented when displaced from the Bahian environment. The Mercadão de Madureira in Rio de Janeiro, for instance, retains a great variety of ingredients but it is organized very differently. It is located in a shopping centre in the northern part of the city, and it has small shops distributed on two floors. Some shops sell clothes, garments, bead necklaces, images, sets of plates and containers for the assenteamentos, and similar items. Another part of the market is solely dedicated to the sale of fresh leaves, while at other stalls live animals can be acquired for sacrifice. As can be observed, the Mercadão of Madureira responds to the needs of a specialized market without being isolated from other local businesses targeted at a more general public, and while being completely integrated into the wider social fabric of the city.

Conversely, the area of São Paulo does not offer similar examples of big marketplaces for acquiring specialist items for Candomblé or Umbanda. Rather, those articles can be bought in small shops located in the sprawling streets of the city and in different neighbourhoods. These stores (also called casa de umbanda) are mostly run by people who are familiar with Afro-Brazilian religions. Reginaldo Prandi, in his important work on the Candomblé of São Paulo, observes that the majority of these shops are located in the city centre, close to the municipal market. However, he argues that: "In São Paulo, there are three things that the observer will always notice in every neighbourhood of the periphery: a Pentecostal church, a casa de umbanda and a gym [...]." ${ }^{\prime 20}$ The participants in most Candomblé and Umbanda houses I attended in São Paulo acquire the ingredients and items they need in these small shops located around the city.

However, for Pai Mauro and his overseas terreiro, the acquisition of both ingredients for the offerings and religious items is a more difficult and expensive process. In fact, ingredients such as manioc flour, yams and palm oil are rare, expensive and often of poor quality in Italy, and they can be found only in small shops targeted at African or Asian immigrants. For these reasons, the Candomblé community of Arborio developed creative ways of acquiring, preserving, storing and substituting those

\footnotetext{
${ }^{19}$ Ibidem.

${ }^{20}$ R. Prandi, Os candomblés de São Paulo. A velha magia na metrópole nova, São Paulo 1991,
} p. 201. 
items that are almost completely absent in Italy but that can be acquired through the globalized production and distribution chain.

The first type of substitution concerns the fact that Pai Mauro needs to rely on those ingredients that are produced and sold for the African or Asian markets and then exported to Europe, as the same ingredients produced in Brazil are not commonly available on the global market. Therefore, in the kitchen of the Italian Candomblé house, there can be found black eyed beans from Nigeria, manioc flour from Togo or Ivory Coast, and palm oil from Ghana. Dried shrimps come from Thailand and banana leaves are produced in Vietnam and sold frozen for the global market. However, other ingredients commonly used for offerings, such as olive oil, rice or honey, are produced and acquired in Italy. Similarly, herbal baths are prepared with fresh herbs that can be grown locally. In Candomblé, different plants are associated with different orixás and employed to make herbal baths or similar ritual preparations. For example, in Brazil it is common to use coffee leaves for the rituals dedicated to Oxalá. However, coffee leaves are almost impossible to grow in the temperate climate of Piedmont, so Pai Mauro started substituting them with rosemary, which is also a plant dedicated to Oxalá, but less common in Brazil. The so-called "wild" or "forest" space of the terreiro of Arborio contains different plants that can be used for the rituals but that also represent the typical vegetation of an Italian back garden: rosemary, laurel, peppermint, lavender, and myrtle, but also vines and peach and mulberry trees. Other plants such as peregun (Dracaena) and boldo have been imported from Brazil and are kept indoors during the winter season.

In this constant game of association and deferral between symbols, plants and deities, the Italian Candomblé changes the textures, smells and flavours of its offerings by creatively using material ingredients that represent variations of the traditional rules. These "variations on a theme" are endorsed by the need to adapt to a new ecological, social and economic background, relying on what is available on the Italian market and what can be imported from the global distribution of food from the Global South to Europe.

Nowadays, small shops selling religious items for Afro-Brazilian religions are present in countries like Portugal, where there is a higher percentage of migrants from Brazil and South America, and where several Candomblé and Umbanda houses have been active for a few decades..$^{21}$ The lack of a proper market of religious items in Italy required some specific ingredients to be shipped or imported from Brazil by Brazilian and Italian practitioners who travel between the two countries. Interestingly, this process of substitution, adaptation and occasional importation has been fundamental in the early formation of Afro-Brazilian Candomblé. Voeks reminds us how some plants and ingredients have been imported to Brazil from West Africa by travellers, friends and sympathisers of the terreiros. Such is the case of the French ethnologist and photographer Pierre Verger, often referred to as a "messenger between two worlds", who, at the request of his Candomblecist interlocutors, travelled

${ }^{21}$ C. Saraiva, Blood, Sacrifices and Religious Freedom: Afro-Brazilian Associations in Portugal, [in:] Site and Politics of Religious Diversity in Southern Europe: The Best of All Gods, J. Mapril, R.L. Blanes (eds.), Leiden 2013, p. 170. 
to Nigeria and brought back to Brazil some cuttings of akokô, an endemic plant of Cameroon that is now relatively common in Salvador. ${ }^{22}$ Anthropologists played and continue to play an important role in the shaping of cultural practices. During my fieldwork I happened to bring things like clothes or kola nuts from Brazil to Italy to satisfy the requests of my interlocutors. However, in this case the actual "messenger between two worlds" (this time between Brazil and Europe) is Pai Odé, who has been working for more than a decade in the Festival Latino-Americando of Assago. In this unusual setting, Pai Odé attends clients who pay for a divination session with the cowrie shells, but he also sells images, statues, charms, herbs, soaps and other items, together with other souvenirs and artisanal objects from Brazil. Pai Odé created a hybrid enterprise between a thematic gift-shop and a religious items store, which fits the evocative context of the Latin Festival but also responds to the needs of his Italian clients and sympathizers.

In this setting, Pai Odé resembles more the iconic fortune-teller that populated the fairs and markets of the sixteenth century than a Candomblé priest. Studies show how the use of tarot cards as a divination tool can be traced back to the French occultists of the sixteenth century, although the character of the fortune-teller was already present in popular culture. ${ }^{23}$ Indeed, magico-religious practices have been historically present in Europe: the work of Ernesto De Martino, Magic: A Theory from the South (Chicago), is a detailed ethnographic description of sorcery and exorcism in the region of Lucania, in Southern Italy in 1959, where a mixture of Catholic prayers and ceremonial magic was employed to free infants and adults from the evil eye. Similar practices have been analysed by the work of Favret-Saada, Deadly Words: Witchcraft in the Bocage (Cambridge), who took into account magic spells and sorcery in rural France in the 1970s. Moreover, it is important to note that the esoteric side element in Afro-Brazilian religions has been likely influenced by European magic practices and beliefs. The ways in which religious phenomena across the Atlantic Ocean engaged in a dialogue with the European imaginary has been analysed by authors such as the historian Laura de Mello e Sousa, ${ }^{24}$ who explored the overlapping of witchcraft and African religious practices in the imaginary of colonial Brazil, using rich historical material from the Spanish Inquisition trials. As she argues, Afro-Brazilian practices have been regarded as forms of sorcery and suffered persecution and discrimination, and the collective memory and the dominant colonial discourse that associated practices of African origin with black magic and evil forces were informed by a European popular imaginary.

Why did history not coincide with memory? Why were the witches that existed in the Brazilian imagination European, if historical evidence documented a different kind of sorcery, one that was predominantly African? Was popular memory entirely sideswiped by the ideology of colonization, with Brazil having become, in its dreams and fantasies, a larger Portugal? ${ }^{25}$

${ }^{22}$ R.A. Voeks, op. cit., pp. 31-32.

${ }^{23}$ H. Farley, A Cultural History of Tarot. From Enterteinment to Esotericism, London 2009, p. 22.

${ }^{24}$ L. de Mello e Souza, Sorcery in Brazil: History and Historiography, [in:] Sorcery in the Black Atlantic, L. N. Parés, R. Sansi (eds.), Chicago 2001, pp. 41-54.

${ }^{25}$ Ibidem, p. 50. 
The compelling presence of witches and ecstatic rituals in agrarian cults in Northern Italy has been well-documented by authors such as Carlo Ginzburg in his books Ecstasies: Deciphering the Witches' Sabbath (Chicago), and The Night Battles: Witchcraft \& Agrarian Cults in the Sixteenth \& Seventeenth Centuries (Baltimore).

In order to better describe how this historical imaginary affects the perception of Candomblé in this particular area, I will describe the case of a despacho (offerings left in nature) found on the streets of Paderno Dugnano, close to Milan, in July 2017 (that had not been placed by my interlocutors). The news was covered by the local newspaper "Il Giorno," titled: "Paderno: The Mystery of the Altar with the Slaughtered Chickens. ${ }^{" 26}$ According to the article, the offerings consisted of two clay dishes containing two sacrificed chickens, candles, coins, cigars, beans, champagne, a Brazilian liquor, fruit, and flowers. The article presumed that the offerings were part of a religious or magical ritual, and also mentioned that local inhabitants were horrified by the scene and that the police were already investigating the case. As can be observed, the unusual discovery of a despacho caused concern for a variety of reasons connected to public decency and irrational fear. The scene that the article described as "disturbing" or "macabre" contains elements which resonate with the imaginary of witches, Sabbaths and similar elements present in the Italian folkloric tradition, but also with cases of Satanist sects, esoteric symbols, and animal and human sacrifices that have been overexposed by the national and international press in the last two decades. ${ }^{27} \mathrm{I}$ argue that the prejudices and perceptions of Afro-Brazilian practices like the despachos, are in the Italian territory informed by local cultural and historical factors and are readily associated with esotericism, black magic and even crime.

Indeed, it emerged from the interviews that many of the Italian initiates, before getting in touch with the terreiro of Arborio, had previously shown interest in a variety of magic practices such as mediumship, chiromancy and tarot reading.

At some point I started reading the tarot without knowing anything about it, and whatever I said... it happened! So, I think there are people who [...] can see behind, I believe so, because sometimes I used to go to the fortune-teller myself. (sacred daughter)

I was already interested in solomonic magic. (sacred daughter)

[talking about a medium he used to visit] You enter in his room [...] and he starts talking. He barely looks at you, and he tells to you everything about yourself, everything! [...] He does not miss a thing! (ogãn)

Clara Saraiva ${ }^{28}$ singles out different reasons for the popularity of Afro-Brazilian religions in Europe. Firstly, these ritual practices are seen as a continuum of Southern European mysticism and magico-religious practices and beliefs, without necessarily

${ }^{26} \mathrm{http}: / / w w w . i l g i o r n o . i t / s e s t o / c r o n a c a / p a d e r n o-g a l l i n e-u c c i s e-1.3268910$ [access: 27.09.2018].

27 Indeed, that same area in the Northern periphery of Milan (especially the municipalities of Busto Arsizio and Somma Lombarda) has been the location of one of the most infamous criminal cases in Italy's recent history: a series of murders and crimes perpetuated by a group of self-proclaimed adepts of a satanic sect called the "Beasts of Satan", between 1998 and 2004 (L. Offeddu, F. Sansa, I Ragazzi di Satana: la setta delle bestie alla scoperta di un'Italia sconosciuta, Milan 2005).

${ }^{28}$ C. Saraiva, Blood, Sacrifices and Religious Freedom..., op. cit., pp. 131-132. 
contradicting Catholic cultural heritage. ${ }^{29}$ Secondly, Afro-Brazilian cults are "religions of afflictions" that often help devotees overcome life-crises. Lastly, these religions have strong performative and emotional traits which are regarded as particularly appealing, in contrast to the rigour of the Catholic doctrine and ritual. While, as a general rule, it is true that Italian clients and initiates, especially according to what has been observed in Pai Mauro's terreiro, often perceive Candomblé as another practice in the market of magico-religious services, these transcultural encounters are never frictionless, especially when the question of religious identity is at stake.

Pai Mauro's first approach to Candomblé was also through his professional interests as a fortune-teller. When I asked him about how the Candomble house is perceived by the population of Arborio and the surrounding villages, he explained brilliantly the role of his profession in giving an acceptable image to the terreiro:

Pai Mauro: Since I put the advertisement sign with my face on it [offering magical services] along the road, everybody understood the professional function [of the terreiro] [...] the two things matched, they said "Mauro is a professional and he also does other things that are relevant," so as bizarre as it can appear [...] here it's better to have a wizard than a pai de santo.

\section{Conclusion}

As has been observed, the landscape is a dynamic social construct in which cultural and environmental elements intertwine. The intentions and perceptions of human actions contribute to the shaping of the environment, but are also influenced by it at the same time. In these multiple diasporas from the romanticized African social and ecological landscape to Brazil, and from Brazil to other countries, the forested space (often depicted as an ideal uncontaminated forest) has the ability to shift and shrink into a portion of Atlantic forest, a plot of land, a back garden or a potted plant. However, in the eyes of Candomblé practitioners, these re-territorialized gardens and forests retain the symbolic elements and the ritual properties that allow the cult of the orixás to be performed in different contexts. With these premises, it could be argued that the orixás themselves can be described as lenses through which Candomblé followers perceive the environment. Despite the inhomogeneity of the Brazilian ecological landscape and the climatic peculiarities of the Italian case, the orixás provide a pattern of associations among natural elements, food items, colours and symbols in which rivers, woods, oceans and other elements can be "read" and understood in different contexts. This process of adaptation is replicated in the fragmentation of the market as a physical and imaginary place where ritual items are acquired, but also where a shared notion of what is being sold or exchanged in the transaction is produced. In the Italian case, the set of ritual practices, artefacts and elements related to the orixás overlap with a pre-existent imaginary, are inserted in the realm of the "magic" and "supernatural" and, in this way, are repositioned in a shared universe of meaning.

${ }^{29}$ Devotional practices related to popular Catholicism in Portugal, especially concerning healing practices and their intersections with the Afro-Brazilian world, have been explored by several authors, in particular see: C. Bastos, Omulu em Lisboa: etnografias para uma teoria da globalização, "Etnográfica" 2001, vol. 5, no. 2, pp. 303-324. 


\section{References}

Afolabi Ojo G.J., Yoruba Palaces: A Study of Afins of Yorubaland, London 1966.

Bahia J., De Miguel Couto a Berlim: a presença do candomblé brasileiro em terras alemãs, [in:] Migração e globalização: um olhar interdisciplinar, G.M.S. Pereira, J. de Ribimar Souza Pereira (eds.), Curitiba 2012, pp. 181-212.

Balée W., Historical Ecologies: Premises and Postulates, [in:] Advances in Historical Ecology, W. Balée (ed.), New York 1998, pp. 13-29.

Barber K., How Man Makes God in West Africa: Yoruba Attitudes towards the 'Orisa', "Africa: Journal of the International African Institute" 1981, no. 51(3), pp. 734-745.

Bastide R., O Candomblé da Bahia, São Paulo 2005.

Bastos C., Omulu em Lisboa: etnografias para uma teoria da globalização, "Etnográfica" 2001, vol. 5, no. 2, pp. 303-324.

Capone S., Searching for Africa in Brazil. Power and Tradition in Candomblé, London 2010.

Carney J.A., Rosomoff R.N., In the Shadow of Slavery. Africa's Botanical Legacy in the Atlantic World, Berkeley 2009.

Descola P., In the Society of Nature: A Native Ecology of Amazonia, Cambridge 1994.

Farley H., A Cultural History of Tarot. From Entertainment to Esotericism, London 2009.

Favret-Saada, J., Deadly Words: Witchcraft in the Bocage, Cambridge 1980.

De Martino E. Magic: a theory from the South. Chicago 2015.

Halloy A., Um candomblé na Bélgica. Traços etnográficos de uma tentativa de instalação e suas dificuldades, "Revista de Antropologia - USP" 2004, no. 47(2), pp. 453-493.

Ingold T., Rethinking the Animate, Re-Animating Thought, "Ethnos: Journal of Anthropology" 2011, no. 71(1), pp. 9-20.

Mello e Souza L. de, Sorcery in Brazil: History and Historiography, [in:] Sorcery in the Black Atlantic, L.N. Parés, R. Sansi (eds.), Chicago 2001, pp. 41-54.

Offeddu L., Sansa F., I Ragazzi di Satana: la setta delle bestie alla scoperta di un'Italia sconosciuta, Milano 2005.

Prandi R., Os candomblés de São Paulo. A velha magia na metrópole nova, São Paulo 1991.

Preston J., Spiritual Magnetism: An Organizing Principle for the Study of Pilgrimage, [in:] Sacred Journeys: The Anthropology of Pilgrimage, A. Morinis (ed.), London 1992, pp. 31-45.

Santos J.E. dos, Os Nagô e a morte: pàde, àsèsè e o culto égun na Bahia, Petrópolis 2002.

Saraiva C., Afro-Brazilian religions in Portugal: bruxos, priests and pais de santo, "Etnográfica" 2010, no.14 (2), pp. 265-288.

Saraiva C., Blood, Sacrifices and Religious Freedom: Afro-Brazilian Associations in Portugal, [in:] Site and Politics of Religious Diversity in Southern Europe: The Best of All Gods, J. Mapril, R.L. Blanes (eds.), Leiden 2013, pp. 129-154.

Sheridan M.J., The Dynamics of African Sacred Groves: Ecological, Social and Symbolic Processes, [in:] African Sacred Groves: Ecological Dynamics and Social Change, M.J. Sheridan, C. Nyamweru (eds.), Oxford 2008, pp. 9-41.

Sodré M., O terreiro e a cidade: a forma social Negro-Brasileira, Rio de Janeiro 2002.

Teisenhoffer V., Umbanda, New Age et psychothérapie. Aspects de l'implantation de l'umbanda à Paris, "Ateliers du LESC" 2007, no. 31, http://journals.openedition.org/ateliers/872 [access: 08.12.2018].

Vásquéz M.A., Rocha C., Introduction: Brazil in the New Global Cartography of Religion, [in:] idem, The Diaspora of Brazilian Religions, Leiden 2013, pp. 1-42.

Voeks R.A., Sacred Leaves of Candomblé: African Magic, Medicine and Religion in Brazil, Austin 1997.

Vogel A., Mello M.A.S., Barros J.F.P., A galinha-d'angola: iniciação e identidade na cultura afrobrasileira, Rio de Janeiro 1993. 